\title{
PEMBERIAN MAKANAN PENDAMPING ASI DAN KERAGAMAN KONSUMSI SUMBER VITAMIN A DAN ZAT BESI USIA 6-23 BULAN DI PROVINSI BENGKULU (ANALISIS DATA SDKI 2017)
}

\author{
Depri Aryani, Arie Krisnasary, Betty Yosephin Simanjuntak* \\ Jurusan Gizi, Poltekkes Kemenkes Bengkulu \\ Jl. Indragiri Pd. Harapan No. 3 Padang Harapan, Kec. Gading Cempaka Kota Bengkulu, Bengkulu, 38225 \\ Korespondensi: E-mail: patricknmom@yahoo.co.id
}

\begin{abstract}
Background: The First 1000 Days of Life is the most critical period to improve children's physical and cognitive development. Ages up to 6 months are only given exclusive breastfeeding. The activity of babies after the age of 6 months is increasing so that complementary foods from breast milk are needed to meet the nutritional needs for the development and growth of babies. The right time for giving MP-ASI to children is at the age of 6-24 months since the baby's digestion is begin to strong.

Objectives: This research has determine the relationship between complementary feeding and consumption of vitamins $A$ and Iron aged 6-23 months in Bengkulu Province.

Methods: This study uses secondary data from the results of the 2017 IDHS which was carried out with quantitative approach with a cross sectional design. The subjects in this study were 93 children aged 6-23 months. This study uses data collected from the 2017 IDHS with a questionnaire observation method for a sample of children aged 6-23 months. The analysis used was chi-square.

Results: Children aged 6-23 months who were given complementary feeding according to age were 51.7\%. The diversity of micronutrients (vitamin A) source of consumption did not vary by 52.7\%, and sources of iron by $79.8 \%$. There was no significant relationship between the provision of complementary feeding with vitamin A and Iron sources of consumption aged 6-23 months in Bengkulu province, respectively, p-value 1.000 and 0.484.

Conclusion: Complementary feeding is still not age-appropriate and contributes to the diversity of consumption of nutritional sources of vitamins A and Iron
\end{abstract}

Keywords: Complementary feeding; Vitamin A; Iron.

\begin{abstract}
ABSTRAK
Latar Balakang: Masa 1000 Hari Pertama Kehidupan (HPK) merupakan masa paling kritis untuk memperbaiki perkembangan fisik dan kognitif anak. Usia hingga 6 bulan hanya diberikan ASI eksklusif saja. Aktivitas bayi setelah usia 6 bulan semakin banyak sehingga diperlukan makanan pendamping dari ASI guna memenuhi kebutuhan gizi untuk perkembangan dan pertumbuhan bayi. Waktu pemberian MP-ASI anak yang tepat adalah usia 6-24 bulan, pada usia tersebut pencernaan bayi mulai kuat.

Tujuan: Peneltian ini bertujuan untuk mengetahui hubungan antara pemberian makanan pendamping ASI (MP-ASI) dengan konsumsi sumber vitamin A dan Fe usia 6-23 bulan di Provinsi Bengkulu.

Metode: Penelitian ini menggunakan data sekunder dari hasil Survei Demografi dan Kesehatan Indonesia (SDKI) 2017 yang dilaksanakan dengan pendekatan kuantitatif menggunakan rancangan cross sectional. Subjek dalam penelitian ini berjumlah 93 balita berusia 6-23 bulan. Penelitian ini menggunakan data hasil pengumpulan SDKI 2017 dengan metode observasi kuesioner terhadap sampel anak usia 6-23 bulan. Analisis yang digunakan adalah chi-squar.e

Hasil: Anak usia 6-23 bulan yang diberikan MP-ASI sesuai dengan umur sebanyak 51,7\%. Keragaman konsumsi sumber zat gizi mikro (vitamin A) tidak beragam $52,7 \%$, dan sumber zat besi sebesar 79,8\%. Tidak terdapat hubungan yang signifikan antara pemberian MPASI dengan konsumsi sumber zat gizi mikro (vitamin A) dan konsumsi sumber zat gizi mikro (Fe) usia 6-23 bulan di provinsi Bengkulu masing-masing p-value 1,000 dan 0.484.

Simpulan: Pemberian MPASI masih belum sesuai umur dan berkontribusi terhadap keragaman konsumsi sumber zat gizi vitamin A dan Fe
\end{abstract}

Kata Kunci: Makanan Pendamping ASI (MPASI); Vitamin A; Zat Besi. 


\section{PENDAHULUAN}

Baduta merupakan sebutan yang ditujukan untuk anak usia bawah dua tahun atau sekitar 0-24 bulan. ${ }^{1}$ Masa 1000 Hari Pertama Kehidupan (HPK) merupakan periode yang bermula sejak saat konsepsi hingga anak berusia 2 tahun. Periode ini paling kritis karena tidak dapat diperbaiki apabila terjadi gangguan perkembangan fisik dan kognitif anak. ${ }^{2}$ Dua tahun pertama kehidupan anak merupakan masa periode emas untuk pertumbuhan fisik tercepat dalam daur kehidupan dan perkembangan otak yang tidak akan pernah terulang. Pada masa ini sel otak mengalami pertumbuhan yang optimal, kekurangan gizi pada masa ini dapat menyebabkan gagal tumbuh dan berakibat buruk dimasa yang akan datang. ${ }^{3}$

Kementrian Kesehatan dan Ikatan Dokter Anak Indonesia (IDAI) telah menegaskan bahwa usia hingga 6 bulan hanya diberikan ASI eksklusif saja. Oleh karena itu, Makanan Pendamping Air Susu Ibu (MPASI) baru bisa diperkenalkan kepada bayi ketika bayi berusia 6 bulan keatas. Aktivitas bayi setelah usia 6 bulan semakin banyak sehingga diperlukan makanan pendamping ASI sehingga terpenuhi kebutuhan gizi harian bayi. Dengan bertambahnya usia bayi, pertumbuhan yang sangat pesat sehingga bayi memerlukan asupan yang lebih banyak. ${ }^{4}$ Waktu pemberian MP-ASI anak yang tepat adalah usia 6-24 bulan, pada usia tersebut organ pencernaan bayi mulai kuat menerima makanan yang tinggi energi. ${ }^{5}$

MP-ASI yang baik mencakup makanan yang beragam untuk memenuhi kebutuhan zat gizi, termasuk zat gizi mikro. MPASI harus diberikan tepat waktu (diberikan mulai umur 6 bulan ke atas), cukup (jumlah, frekuensi, konsistensi, dan keragaman), dan tekstur makanan diberikan sesuai dengan umur anak. Kelompok makanan hewani, buah, dan sayur harus ditambahkan dalam MPASI ini. Berbagai studi menunjukkan bahwa MPASI berbasis kelompok makanan nabati saja tidak cukup untuk memenuhi zat gizi mikro tertentu. Oleh karena itu, baik kelompok makanan hewani maupun buah dan sayur harus ditambahkan dalam MPASI ini. $^{6}$

Laporan SDKI tahun 2017 menyebutkan persentase konsumsi MPASI di Provinsi Bengkulu pada anak usia 6-23 bulan yang tidak mendapat ASI lebih tinggi dibandingkan dengan anak yang mendapat ASI (36,8\% dibanding 24,2\%). Kelompok makanan tersebut diantaranya buah dan sayuran sumber vitamin A (81\% dibanding 53\%), buah dan sayuran lainnya (31\% dibanding 11\%), makanan dari kacang-kacangan $(36 \%$ dibanding $33 \%)$, daging/ikan/daging unggas (67\% dibanding $54 \%)$, dan telur (58\% dibanding 31\%). Pola konsumsi MPASI pada usia 6-23 bulan paling dominan pada makanan yang bersumber dari serealia baik pada anak yang tidak mendapat ASI (95\%) dan yang mendapatkan ASI $(60 \%)$.

Riskesdas tahun 2018 melaporkan proporsi keragaman konsumsi makanan yang beragam pada anak umur 6-23 bulan secara nasional sebesar 46,6\% dan Provinsi Bengkulu masih di bawah angka nasional yaitu $45,9 \%$. Keragamam konsumsi makanan dikategorikan berdasarkan serealia, umbiumbian, kacang-kacangan, susu dan olahannya, daging, ikan, ayam, hati, telur, sayur dan buah sumber vitamin A, sayur dan buah lainnya. Keberagaman konsumsi makanan usia 6-23 bulan terendah pada kelompok umur 6-11 bulan yaitu $29,8 \%$, dan tertinggi pada usia 20-23 bulan sebesar $60,5 \%$. Data ini menunjukan bahwa keberagaman konsumsi makanan pada anak masih sangat rendah. Persentase anak yang mengonsumsi makanan kaya vitamin A dan zat besi di Provinsi Bengkulu menurun dalam 10 tahun terakhir, yaitu dari $91 \%$ pada SDKI tahun 2007 menjadi 85\% pada SDKI tahun 2017 untuk makanan kaya vitamin A; dan dari 74\% pada SDKI tahun 2007 menjadi 67\% pada SDKI tahun 2017 untuk makanan kaya zat besi. ${ }^{7}$

Di Indonesia, defisiensi zat gizi mikro cukup tinggi terlihat $54 \%$ anak mengalami defisiensi vitamin A, 50\% anemia defisiensi besi dan $17 \%$ defisiensi zink. Kekurangan vitamin A dapat mempengaruhi sintesis protein, sehingga mempengaruhi pertumbuhan dan diferensiasi sel. Suplementasi vitamin A yang diberikan hanya satu kali dilaporkan dapat menurunkan mortalitas dan morbiditas. Oleh karena itu, anak yang kekurangan vitamin A akan mengalami kegagalan tumbuh kembang. Selain itu, vitamin A sangat mempengaruhi fungsi kekebalan tubuh manusia sehingga rentan terhadap terjadinya penyakit infeksi, misalnya jika terjadi pada permukaan dinding usus maka akan menyebabkan diare. ${ }^{8}$

Hasil studi di berbagai negara di dunia juga menunjukkan prevalensi defisiensi besi masih menjadi masalah kesehatan pada anak usia 6-23 bulan antara lain di Vietnam $12,9 \% .^{9}$ Di New Zealand $18,6 \%$ anak menderita deplesi simpanan besi dan di Korea 23,6\% anak menderita defisiensi besi sangat berat pada anak usia 6-23 bulan terutama pada usia 12-23 bulan dapat disebabkan oleh tingkat asupan zat besi, vitamin A, folat dan zink yang rendah dari makanan. ${ }^{10}$ Tujuan penelitian ini untuk menganalisis hubungan pemberian makanan pendamping ASI (MP-ASI) dengan konsumsi sumber zat gizi mikro (vitamin A dan $\mathrm{Fe}$ ) usia 6-23 bulan di provinsi Bengkulu (Analisis Data SDKI 2017). 


\section{METODE}

Penelitian ini menggunakan data sekunder dari hasil SDKI 2017 yang dilaksanakan dengan pendekatan kuantitatif dengan rancangan cross sectional, yaitu seluruh variabel baik independen maupun dependen dikumpulkan pada waktu yang sama. Variabel terikat (dependent variabel) pada penelitian ini adalah keragaman konsumsi sumber zat gizi mikro (vitamin A dan $\mathrm{Fe}$ ). Sedangkan variabel bebas (independent variabel) adalah makanan pendamping ASI (MP-ASI).

Data sekunder SDKI 2017 merupakan berskala nasional dengan responden sejumlah 49.250 rumah tangga, 59.100 wanita pernah kawin berusia 15-49 tahun. Populasi dalam penelitian ini adalah semua responden wanita usia subur yang berusia 15-49 tahun, seluruh anak terakhir yang lahir dalam dua tahun sebelum survei, bertempat tinggal pedesaan dan perkotaan di provinsi Bengkulu berjumlah 1428 orang. Sampel yang tercakup dalam penelitian ini adalah yang memenuhi kriteria inklusi yaitu anak hidup, kelahiran terakhir, tidak kembar, tinggal bersama ibu, berumur 0-23 bulan dan lahir dari ibu berumur 15-49 tahun. Kriteria eksklusi adalah ibu yang memiliki kondisi yang tidak bersedia menjadi responden. Sampel dalam penelitian ini adalah anak yang berusia 6-23 bulan di wilayah Provinsi Bengkulu dan yang memiliki data lengkap sesuai dengan variabel penelitian yaitu berjumlah 93 anak.

Kuesioner yang digunakan dalam SDKI telah melalui proses uji coba oleh Badan Pusat Statistik (BPS). Kuesioner variabel pemberian MPASI terdapat pada kuesioner SDKI 2017 bagian 6. Kesehatan gizi dan anak pertanyaan nomor 652 , sedangkan pada variabel dependen yaitu konsumsi sumber zat gizi mikro terdapat pada pertanyaan nomor 650 (i-t) yang dikelompokan atas sumber bahan makanan terbuat dari biji-bijian, buah dan sayur kaya vitamin A, umbi-umbian, sayuran hujau, sayur \& buah lainnya, hati \& organ hati, daging/ikan/daging unggas, kacang-kacangan serta susu \& produk olahannya. Analisis data dilakukan secara univariat, bivariat dengan menggunakan uji chi square.

\section{Tabel 1. Karakteristik Subjek dan Responden}

\begin{tabular}{|c|c|c|}
\hline $\begin{array}{r}\text { Karakteristik } \\
\end{array}$ & $n$ & $\%$ \\
\hline \multicolumn{3}{|l|}{ Usia bayi (Bulan) } \\
\hline $6-9$ & 45 & 48,3 \\
\hline $9-12$ & 12 & 12,9 \\
\hline $12-23$ & 36 & 38,8 \\
\hline Total & 93 & 100 \\
\hline \multicolumn{3}{|l|}{ Usia Ibu } \\
\hline $22-30$ Tahun & 16 & 17,2 \\
\hline $31-35$ Tahun & 46 & 49,4 \\
\hline $36-43$ Tahun & 31 & 33,4 \\
\hline Total & 93 & 100 \\
\hline \multicolumn{3}{|l|}{ Tempat Tinggal } \\
\hline Perkotaan & 36 & 38,7 \\
\hline Pedesaan & 57 & 61,3 \\
\hline Total & 93 & 100 \\
\hline \multicolumn{3}{|l|}{ Pekerjaan Ibu } \\
\hline Bekerja & 37 & 39,8 \\
\hline Tidak Bekerja & 56 & 60,2 \\
\hline Total & 93 & 100 \\
\hline \multicolumn{3}{|l|}{ Pendidikan Ibu } \\
\hline SD & 28 & 30,1 \\
\hline SMP & 25 & 26,9 \\
\hline SMA & 32 & 34,4 \\
\hline Diploma 1, 2, 3 & 2 & 2,2 \\
\hline Diploma 4/S1 & 6 & 6,5 \\
\hline Total & 93 & 100 \\
\hline \multicolumn{3}{|l|}{ Pemberian MPASI } \\
\hline Sesuai umur & 49 & 52,7 \\
\hline Tidak sesuai umur & 44 & 47,3 \\
\hline Total & 93 & 100 \\
\hline \multicolumn{3}{|c|}{ Konsumsi Zat Gizi Mikro (Vitamin A) } \\
\hline Beragam & 30 & 32,3 \\
\hline Tidak beragam & 63 & 67,7 \\
\hline Total & 93 & 100 \\
\hline \multicolumn{3}{|l|}{ Konsumsi Zat Gizi Mikro (Fe) } \\
\hline Beragam & 44 & 47,3 \\
\hline Tidak beragam & 49 & 52,7 \\
\hline Total & 93 & 100 \\
\hline
\end{tabular}




\section{HASIL}

Subjek penelitian ini sebanyak 48,3\% berusia 6-9 bulan, sementara usia responden yakni ibu mayoritas 31-35 tahun berjumlah 46 orang $(49,4 \%)$ dan sebagian besar $(61,3 \%)$ tinggal di pedesaan.

Mayoritas ibu tidak bekerja $(60,2 \%)$ dengan pendidikan terakhir yaitu SMA $(34,4 \%)$. Diketahui juga jumlah bayi yang diberikan MPASI sesuai umur $(52,7 \%)$ dan tidak beragam mengonsumsi sumber zat gizi mikro (vitamin A) sebanyak $68,2 \%$ serta sebagian besar anak tidak beragam mengonsumsi sumber zat gizi mikro $(\mathrm{Fe})$ sebanyak 47,7\%. Berdasarkan Tabel 2 diketahui jumlah konsumsi bahan makanan yang paling banyak dikonsumsi oleh anak yang berusia 6-23 bulan di Provinsi Bengkulu yaitu sumber bahan makanan dari serealia/biji-bijian berjumlah 57 anak $(61,3 \%)$, sedangkan anak yang paling sedikit mengonsumsi sumber bahan makanan yaitu ikan berjumlah 10 anak $(10,8 \%)$.

Tabel 2. Distribusi Frekuensi Konsumsi Sumber Bahan Makanan pada Anak Usia 6-23 Bulan

\begin{tabular}{|c|c|c|}
\hline \multirow[t]{2}{*}{ Nama Bahan Makanan } & \multicolumn{2}{|c|}{ Frekuensi } \\
\hline & $\mathrm{n}$ & $\%$ \\
\hline Serealia/biji-bijian & 57 & 61,3 \\
\hline Buah \& sayur lainnya & 45 & 48,4 \\
\hline Buah vitamin A & 43 & 46,2 \\
\hline Kacang-kacangan & 40 & 43,0 \\
\hline Hati \& organ lainnya & 40 & 43,0 \\
\hline Umbi-umbian & 38 & 40,9 \\
\hline Telur & 35 & 36,9 \\
\hline Susu \& produk susu & 32 & 34,4 \\
\hline Sayuran hijau & 30 & 32,3 \\
\hline Ikan & 10 & 10,8 \\
\hline
\end{tabular}

Berdasarkan Tabel 3 diketahui jumlah konsumsi bahan makanan yang paling banyak dikonsumsi oleh anak yang berusia 6-9 bulan yaitu sumber bahan makanan dari susu \& produk susu $(31,3 \%)$, usia $9-12$ bulan buah vitamin A $(46,5 \%)$,
Sedangkan jumlah konsumsi bahan makanan yang paling sedikit dikonsumsi oleh anak yang berusia 69 bulan yaitu sumber bahan makanan dari telur (5,7\%), usia 9-12 bulan sayuran hijau (20\%), dan usia 12-23 bulan yaitu buah vitamin A $(30,2 \%)$.

Tabel 3. Distribusi Frekuensi Konsumsi Sumber Bahan Makanan Berdasarkan Kelompok Usia Anak

\begin{tabular}{lcccccc}
\hline Nama Bahan Makanan & \multicolumn{7}{c}{ Usia Anak } \\
\hline & \multicolumn{2}{c}{$\mathbf{6 - 9}$ bulan } & $\mathbf{9 - 1 2}$ bulan & \multicolumn{1}{c}{$\mathbf{1 2 - 2 3}$ bulan } \\
\cline { 2 - 7 } & $\mathrm{n}$ & $\%$ & $\mathrm{n}$ & $\%$ & $\mathrm{n}$ & $\%$ \\
\hline Serealia/biji-bijian & 15 & 26,3 & 17 & 29,8 & 25 & 43,9 \\
Buah dan sayur lainnya & 13 & 28,0 & 13 & 28,0 & 19 & 44,0 \\
Buah vitamin A & 10 & 23,3 & 20 & 46,5 & 13 & 30,2 \\
Kacang-kacangan & 6 & 15,0 & 12 & 30,0 & 22 & 55,0 \\
Hati dan organ lainnya & 3 & 7,5 & 17 & 42,5 & 20 & 50,0 \\
Umbi-umbian & 10 & 26,3 & 11 & 29,0 & 17 & 44,7 \\
Telur & 2 & 5,7 & 11 & 31,4 & 22 & 62,9 \\
Susu dan produk susu & 10 & 31,3 & 8 & 25,0 & 14 & 43,7 \\
Sayuran hijau & 3 & 10,0 & 6 & 20,0 & 21 & 70,0 \\
Ikan & 1 & 10,0 & 3 & 30,0 & 6 & 60,0 \\
\hline
\end{tabular}

Tabel 4 menunjukan bahwa pemberian MPASI berusia 6-23 bulan di Provinsi Bengkulu sesuai umur memiliki kebiasaan mengonsumsi sumber zat gizi mikro (vitamin A) beragam sebanyak 16 anak (32,7\%), Sedangkan anak yang diberikan MPASI tidak sesuai umur memiliki kebiasaan mengonsumsi sumber zat gizi mikro (vitamin A) beragam sebanyak 14 anak $(31,8 \%)$, dan tidak beragam mengonsumsi sumber zat gizi mikro (vitamin A) sebanyak 30 anak (68,2\%). Hasil analisis menunjukan bahwa tidak terdapat hubungan antara pemberian MPASI dengan konsumsi sumber zat gizi mikro (vitamin A) usia 6-23 bulan di Provinsi Bengkulu $(p=1.000>0.05)$.

Tabel 5 menunjukan bahwa 42,9\% anak yang berusia 6-23 bulan di Provinsi Bengkulu diberikan MPASI sesuai umur namun memiliki kebiasaan mengonsumsi sumber zat gizi mikro $(\mathrm{Fe})$ yang 
beragam. Sedangkan anak yang diberikan MPASI tidak sesuai umur sebesar $47,7 \%$ memiliki kebiasaan konsumsi sumber zat besi yang tidak beragam. Hasil analisis menunjukan bahwa tidak terdapat hubungan antara pemberian makanan pendamping ASI (MPASI) dengan keragaman konsumsi sumber zat gizi mikro $(\mathrm{Fe})$ usia 6-23 bulan di Provinsi Bengkulu ( $p=0.484>0.05)$.

Tabel 4. Hubungan Pemberian MPASI dengan Konsumsi Sumber Zat Gizi Mikro (Vitamin A) pada anak usia 6-23 bulan di Provinsi Bengkulu

\begin{tabular}{|c|c|c|c|c|c|c|c|}
\hline \multirow[t]{3}{*}{ Pemberian MP-ASI } & \multicolumn{4}{|c|}{$\begin{array}{c}\text { Konsumsi Sumber Zat Gizi } \\
\text { Mikro (Vitamin A) }\end{array}$} & \multicolumn{2}{|c|}{ Total } & \multirow{3}{*}{$P$ value } \\
\hline & \multicolumn{2}{|c|}{ Beragam } & \multicolumn{2}{|c|}{ Tidak beragam } & \multirow[t]{2}{*}{$\mathrm{n}$} & \multirow[t]{2}{*}{$\%$} & \\
\hline & $\mathrm{n}$ & $\%$ & $\mathrm{n}$ & $\%$ & & & \\
\hline Sesuai Umur & 16 & 32,7 & 33 & 67,3 & 49 & 100 & 1,000 \\
\hline Tidak Sesuai Umur & 14 & 31,8 & 30 & 68,2 & 44 & 100 & \\
\hline Total & 30 & 32,3 & 63 & 67,7 & 93 & 100 & \\
\hline
\end{tabular}

Tabel 5. Hubungan Pemberian Makanan Pendamping ASI (MP-ASI) dengan Konsumsi Sumber Zat Gizi Mikro (Fe) pada Anak Usia 6-23 Bulan di Provinsi Bengkulu

\begin{tabular}{|c|c|c|c|c|c|c|c|}
\hline \multirow[t]{3}{*}{ Pemberian (MP-ASI) } & \multicolumn{4}{|c|}{$\begin{array}{c}\text { Konsumsi Sumber Zat Gizi } \\
\text { Mikro (Fe) }\end{array}$} & \multicolumn{2}{|c|}{ Total } & \multirow{3}{*}{$P$ value } \\
\hline & \multicolumn{2}{|c|}{ Beragam } & \multicolumn{2}{|c|}{ Tidak beragam } & \multirow[t]{2}{*}{$\mathrm{n}$} & \multirow[t]{2}{*}{$\%$} & \\
\hline & $\mathrm{n}$ & $\%$ & $\mathrm{n}$ & $\%$ & & & \\
\hline Sesuai Umur & 21 & 42,9 & 28 & 57,1 & 49 & 100 & 0.484 \\
\hline Tidak Sesuai Umur & 23 & 52,3 & 21 & 47,7 & 44 & 100 & \\
\hline Total & 44 & 47,3 & 49 & 52,7 & 93 & 100 & \\
\hline
\end{tabular}

\section{PEMBAHASAN}

Hubungan Pemberian Makanan Pendamping ASI (MP-ASI) dengan Konsumsi Sumber Zat Gizi Mikro (Vitamin A dan Fe)

Temuan penelitian ini menunjukan bahwa tidak terdapat hubungan yang signifikan antara pemberian MPASI dengan keragaman konsumsi sumber zat gizi mikro (vitamin A dan Fe) usia 6-23 bulan.

Hal ini dikarenakan rata-rata usia anak pada penelitian ini yaitu berusia 6-9 bulan, dimana pada usia ini MPASI yang diberikan berupa makanan bertekstur lumat contohnya seperti bubur susu, bubur buah dan nasi tim saring. ${ }^{11}$ Tentu saja pada usia ini anak kurang mengonsumsi bahan makanan sumber vitamin A dan Fe karena sumber bahan makanan ini diperoleh dari telur, hati, daging dan sumber bahan makanan lainnya yang mengandung vitamin A dan Fe. Sejak usia 6-9 bulan bayi mulai diperkenalkan dengan MPASI lumat 2 kali sehari dengan satu jenis bahan makanan saja dalam menu misalnya jus pepaya, pisang saring, pure kentang. Hal ini menunjukan bahwa makanan bayi tidak beragam karena diperkenalkan secara bertahap. ${ }^{12}$

Analisis data univariat menunjukkan mayoritas anak berusia 6-23 bulan diberikan MPASI sesuai umur. MP-ASI yang baik mencakup makanan yang beragam untuk memenuhi kebutuhan zat gizi, terutama zat gizi mikro. MPASI harus diberikan tepat waktu (diberikan mulai umur 6 bulan ke atas), cukup (jumlah, frekuensi, konsistensi, dan keragaman), dan tekstur makanan diberikan sesuai dengan umur anak. Kelompok makanan hewani, buah, dan sayur harus dimasukkan dalam MPASI. ${ }^{13}$ Berbagai studi juga menunjukkan bahwa MPASI berbasis kelompok makanan nabati saja tidak cukup untuk memenuhi kebutuhan zat gizi mikro tertentu. Oleh karena itu, kelompok makanan hewani, buah, dan sayur harus dimasukkan dalam MPASI. ${ }^{14}$ Tahapan pemberian MP-ASI usia 6-9 bulan sebaiknya makanan bertekstur cair, lembut atau saring, seperti bubur buah, bubur susu atau bubur sayuran saring atau dihaluskan. Menginjak usia 1012 bulan bayi mulai beralih ke makanan kental dan padat, namun tetap bertekstur lunak, seperti aneka nasi tim. Dilanjutkan usia 12-24 bulan anak sudah mulai dikenalkan dengan makanan keluarga atau makanan padat, namun tetap memperhatikan rasa makanan. ${ }^{15}$

Keragaman makanan dapat digunakan sebagai pendekatan dalam menilai kecukupan sumber zat gizi mikro dalam makanan yang dikonsumsi oleh bayi/anak. Keragaman makanan minimal dalam arti paling sedikit ada 4 kelompok makanan dalam menu anak. Konsumsi 4 kelompok makanan ini berhubungan dengan kualitas diet yang lebih baik untuk anak yang mendapat ASI ataupun yang tidak mendapat ASI. Empat kelompok makanan tersebut berasal dari 7 kelompok makanan berikut yaitu umbi-umbian dan biji-bijian, kacang-kacangan, susu dan produk olahannya, daging, telur, buah dan 
sayur sumber vitamin A, serta buah dan sayur lainnya. ${ }^{7}$

Temuan penelitian ini menunjukkan $48,3 \%$ bayi berusia 6-9 bulan banyak mendapatkan MPASI berupa susu \& produk susu $(31,3 \%)$ serta sedikit mengonsumsi sumber bahan makanan telur $(5,7 \%)$. Tentu saja pada usia ini anak kurang mengonsumsi bahan makanan sumber vitamin A dan Fe karena sumber bahan makanan ini banyak terdapat pada telur, hati, daging dan sumber bahan makanan lainnya yang mengandung vitamin A dan Fe. ${ }^{11}$ Sejak usia 6-9 bulan bayi mulai diperkenalkan dengan MPASI lumat 2 kali sehari dengan satu jenis bahan makanan saja dalam menu misalnya bubur susu, pisang saring, pure kentang. Hal ini menunjukan bahwa makanan bayi tidak beragam karena diperkenalkan secara bertahap. ${ }^{12}$

Temuan penelitian Selanjutnya menunjukan 12,9\% bayi berusia 9-12 bulan. Pada usia ini bayi banyak mendapatkan MPASI berupa sumber bahan makanan buah vitamin A $(46,5 \%)$ serta sedikit mengonsumsi sumber bahan makanan sayuran hijau (20\%). Usia 9-12 bulan bayi mulai diperkenalkan MPASI lunak 2 kali sehari dan 1 kali selingan dan dimulai diberikan lebih dari satu jenis bahan makanan sehingga anak pada usia ini mulai diberikan makanan yang beragam terutama sumber zat gizi mikro seperti sumber bahan makanan vitamin A bisa diberikan (wortel, sayuran hijau, telur, hati, papaya) sumber bahan makanan $\mathrm{Fe}$ (daging, unggas, ikan, kacang-kacangan). ${ }^{16}$

Temuan penelitian selanjutnya usia anak 12-23 bulan di Provinsi Bengkulu yaitu sebanyak 38,8\%. Pada usia ini anak lebih sering mengonsumsi sumber bahan makanan telur $(62,9 \%)$ sedangkan $30,2 \%$ anak kurang mengonsumsi buah vitamin $\mathrm{A}$. Usia 12-24 bulan anak mulai diberi makanan keluarga sekurangnya 3 kali sehari dengan porsi separuh makanan orang dewasa setiap kali makan, selain itu variasi makanan juga perlu diperhatikan dengan menggunakan kombinasi bahan makanan seperti bubur susu dapat diganti dengan bubur kacang ijo, bubur sumsum, biscuit dan sumber bahan makanan lainnya. ${ }^{17}$ Berdasarkan kelompok bahan makanan yang dikonsumsi oleh anak usia 623 bulan di Provinsi Bengkulu sebanyak 61,3\% mengonsumsi sumber serealia/biji-bijian, dan $28,7 \%$ anak kurang mengonsumsi sumber zat gizi mikro bersumber dari bahan makanan lainnya seperti sayuran kuning, buah vitamin A, sayuran hijau, hati telur, daging/unggas serta susu dan produk susu lainnya.

Temuan Fatimah \& Wirjatmadi tahun 2018 menunjukkan bahwa rendahnya tingkat asupan zat gizi mikro pada anak dapat disebabkan masih rendahnya kualitas praktik pemberian MPASI, sementara kontribusi energi dan zat gizi dari ASI semakin kecil sesuai pertambahan umur anak. Kontribusi energi dan zat gizi dari ASI setelah 6 bulan berkisar energi $35 \%$, protein $55 \%$ dan zat besi hanya $5 \%$, sedangkan vitamin $\mathrm{A} \pm 80 \%$. Oleh karena itu, untuk pemenuhan kebutuhan anak setelah berusia 6 bulan segera diberikan MPASI meskipun ASI tetap dilanjutkan.

Studi yang dilakukan oleh Sariy et al (2018) banyak faktor penyebab yang berhubungan dengan perilaku pemberian MPASI, di antaranya pengetahuan ibu, pendidikan, pekerjaan ibu, dukungan keluarga, dan kecukupan ASI. Pemberian MPASI yang tidak tepat sangat berkaitan dengan faktor internal dari ibu bayi dan faktor eksternal dipengaruhi oleh lingkungan. Faktor internal meliputi pendidikan, pengetahuan, pekerjaan, sikap, tindakan, psikologis dan fisik dari ibu itu sendiri. Faktor eksternal meliputi faktor budaya, kurang optimalnya peran tenaga kesehatan dan peran keluarga ${ }^{4}$ Analisis univariat pendidikan ibu sebanyak 30,1\% memiliki pendidikan SD (relatif rendah). Hal ini memungkinkan sebagai faktor penyebab pemberian MPASI tidak sesuai umur.

Studi yang dilakukan oleh Saidin S \& Muherdiyantiningsih (2016) menjelaskan bahwa mutu dan jumlah MPASI yang diberikan kepada bayi mempunyai arti penting bagi pemenuhan gizi anak yang terus meningkat dan sangat menentukan tingkat kesehatan maupun gizi. ${ }^{18}$ Selanjutnya diketahui bahwa MPASI yang dikonsumsi dan tidak memenuhi kebutuhan gizi akan berpengaruh dalam tumbuh kembang anak. Oleh karena itu sangat diperlukan MPASI yang mengandung zat gizi mikro yang dibutuhkan tubuh khususnya pada proses tumbuh kembang anak dan membentuk imunitas di tubuh bayi. ${ }^{19}$ Persentase anak yang mengonsumsi makanan kaya vitamin A dan zat besi di Provinsi Bengkulu menurun dalam 10 tahun terakhir, yaitu dari 91\% pada SDKI 2007 menjadi 85\% pada SDKI 2017 untuk makanan kaya vitamin A, dan dari 74\% pada SDKI 2007 menjadi 67\% pada SDKI 2017 untuk makanan kaya zat besi. ${ }^{7}$

Temuan penelitian yang dilakukan oleh Simanjuntak et al (2018) menjelaskan bahwa kekurangan vitamin A kerap terjadi pada anak baduta. Vitamin A berfungsi mempengaruhi sintesis protein, sehingga juga akan berpengaruh terhadap sel pertumbuhan. Oleh karena itu anak yang mengalami kekurangan vitamin A akan dapat menyebabkan kegagalan pertumbuhan. Selain itu vitamin A juga berpengaruh terhadap fungsi kekebalan tubuh manusia. Akibatnya, kekurangan vitamin A menyebabkan penurunan imunitas tubuh, sehingga rentan terhadap infeksi antara lain diare dan ISPA. ${ }^{20}$ 
Penelitian yang dilakukan oleh Lestari et al, (2018) menjelaskan bahwa defisiensi zat besi pada anak akan memberikan dampak yang negatif terhadap pertumbuhan dan perkembangan anak, yaitu dapat menurunkan sistem kekebalan tubuh sehingga meningkatkan kemungkinan terjadinya penyakit infeksi. Selain itu berkurangnya kandungan besi dalam tubuh juga dapat menyebabkan gangguan pertumbuhan organ tubuh akibat oksigenasi ke jaringan berkurang yang berlangsung lama adalah menurunkan daya konsentrasi dan prestasi belajar pada anak. ${ }^{16}$

\section{SIMPULAN}

Pemberian MPASI 6-23 bulan tidak memiliki hubungan dengan keragaman konsumsi sumber zat gizi mikro (vitamin A dan zat besi). Disarankan bagi masyarakat yang memiliki anak baduta untuk memperhatikan pola makan anaknya agar diberikan bahan makanan yang beragam mulai bahan makanan khususnya sumber mikro nutrien, bentuk makanan yang diberikan sesuai umur, dan frekuensi pemberian makanan terutama bagi masyarakat yang memiliki anak berusia 6-23 bulan agar anak dapat tumbuh kembang dengan optimal

\section{DAFTAR PUSAKA}

1. Departemen Kesehatan RI. Pedoman Umum Pemberian Makanan Pendamping Air Susu Ibu (MP-ASI Lokal) Tahun 2006. Jakarta : Depkes RI. 2016.

2. Rahmawati W, Novita Wirawan N, Saptaning Wilujeng C, Fadhilah E, Ari Nugroho F, Yusuf Habibie I, et al. Gambaran masalah gizi pada 1000 HPK di Kota dan Kabupaten Malang (Illustration of nutritional problem in the first 1000 days of life in both city and district of Malang, Indonesia). Indones J Hum Nutr. 2016; 3(1 suplemen): 20-31.

3. Kusumaningrum ND, Hastuti P, Mayasari AC. Hubungan perilaku pemberian MP-ASI dengan status gizi bayi 6-24 bulan di posyandu Desa Bandung Mojokerto. Jurnal Surya. 2019; 11(3): 62-68.

4. Wardhani GK. Hubungan pemberian makanan pendamping ASI dengan status gizi bayi usia 6-24 bulan di kelurahan Satabelan Kota Surakarta Tahun 2015. J Ilm Kesehat Media Husada. 2018; 7(2): 71-78.

5. Aprillia YT, Mawarni ES, Agustina S. Pengetahuan ibu tentang makanan pendamping ASI (MP-ASI). J Ilm Kesehat Sandi Husada. 2020; 9(2): 865-872.

6. Fitriani Y, Firdawati F, Lubis G. Hubungan pemberian jenis makanan pendamping ASI dengan perkembangan bayi umur 9-12 bulan di wilayah kerja puskesmas Lubuk Begalung Padang. J Kesehat Andalas. 2019; 8(4): 238246.

7. Rohmani A. Pemberian makanan pendamping ASI (MP-ASI) pada anak usia 1-2 tahun di kelurahan Lamper Tengah Kecamatan Semarang Selatan, Kota Semarang. Prosiding Seminar Nasional dan Internasional. Semarang : Universitas Muhamadiyah Semarang. 2010. hal. 81-87.

8. Fatimah NSH, Wirjatmadi B. Tingkat kecukupan vitamin A, seng dan zat besi serta frekuensi infeksi pada balita stunting dan non stunting. Media Gizi Indonesia. 2018;13(2):168.

9. Sariy RB, Simanjuntak BY, Suryani D. Pemberian MP-ASI dini dengan status gizi (PB/U) usia 4-7 bulan di Kecamatan Ratu Samban Kota Bengkulu. AcTion Aceh Nutr J. 2018;3(2):103-109.

10. Simanjuntak BY, Haya M, Suryani D, Ahmad CA. Early inititation of breastfeeding and Vitamin A supplementation with nutritional status of children aged 6-59 months. Kesmas : National Public Health Journal. 2018; 12(3): 107-113.

11. Lestari IP, Lipoeto NI, Almurdi A. Hubungan konsumsi zat besi dengan kejadian anemia pada murid SMP Negeri 27 Padang. J Kesehat Andalas. 2018;6(3):507511.

12. Nurdin SSI, Katili DNO, Ahmad ZF. Faktor ibu, pola asuh anak, dan MPASI terhadap kejadian stunting di kabupaten Gorontalo. J Ris Kebidanan Indones. 2019; 3(2): 74-81

13. Arsyati AM, Rahayu YT. Budaya pemberian makanan pendamping ASI (MP-ASI) pada bayi usia kurang dari 6 bulan di desa Leuwibatu Rumpin. Hearty: Jurnal Kesehatan Masyarakat. 2019; 7(1): 9-17.

14. Ilmanisak R, Pudjirahaju A, Aswin AA. Edukasi MP-ASI, Sikap ibu dan tingkat konsumsi energi-protein baduta stunting usia 7-24 bulan. J Pendidik Kesehat. 2017; 6(1): 16-26.

15. Nurlaila N. Perilaku pemberian makanan pendamping ASI (MP-ASI). J Ilm Kesehat Keperawatan. 2019; 15(2): 43-49.

16. Artini B. Analisis faktor yang memengaruhi pemberian MPASI dini. J Kebidanan. 2018; 7(1): 46-52.

17. Nurkomala $S$, Nuryanto N, Panunggal B. Praktik pemberian Mpasi (makanan pendamping air susu ibu) pada anak stunting 
dan tidak stunting usia 6-24 bulan. Journal of Nutrition College. 2018; 7(2): 45-53.

18. Sutriana VN. Determinan pemberian MPASI dini pada bayi 0-6 bulan di wilayah pedesaan Kabupaten Tuban. Berita Kedokteran Masyarakat. 2018; 34(5):1.

19. Fitriana EI, Anzar J, HZ HN, Theodorus T. Dampak usia pertama pemberian makanan pendamping ASI terhadap status gizi bayi usia 8-12 bulan di Kecamatan Seberang Ulu I Palembang. Sari Pediatri. 2013; 15(4): 249-253.

20. Wahyunita VD, Sulatriningsih K, Harahap IZ. Faktor yang mempengaruhi pemberian vitamin A pada balita di kelurahan Ciriung Cibinong Kabupaten Bogor. Quality: Jurnal Kesehatan. 2019; 13(2): 50-53. 